\title{
Kloning Gen $p c b C$ dari Penicillium chrysogenum ke dalam Plasmid pPICZA untuk Pengembangan Produksi Penisilin G
}

\author{
Risma Wiharyanti ${ }^{1}$, Dudi Hardianto ${ }^{2}$, Hermin Pancasakti Kusumaningrum ${ }^{1}$ dan \\ Anto Budiharjo 1 \\ 1. Jurusan Biologi, Fakultas Sains dan Matematika, Universitas Diponegoro, Tembalang, Semarang \\ Telepon (024) 7474754; Fax. (024) 76480690 \\ 2. Balai Pengkajian Bioteknologi, Badan Pengkajian dan Penerapan Teknologi (BPPT), \\ Gd.630 PUSPIPTEK Serpong, Telepon: (021) 7563120 \\ email: wiharyanti.risma@gmail.com
}

\begin{abstract}
Availability of drugs in Indonesia is still limited by the high prices of drugs due to on the imported raw materials that reaches $95 \%$. Developing antibiotic raw materials can be achieved by increasing of penicillin $\mathrm{G}$ production, which is the raw material for the formation of semisynthetic penicillin derivatives through the production of 6-aminopenisillanic acid (6-APA). One of the important enzyme in the penicillin G biosynthesis is Isopenisilin N Synthase (IPNS) that encodes by $p c b C$ gene on Penicillium chrysogenum. This study aimed to obtain a recombinant of $p c b C$ gene fragments that is inserted into pPICZA plasmid. Amplification of $p c b C$ gene used pcbC-F and pcbC-R primers. The $p c b C$ gene fragment was inserted into pPICZA vector and then transformed into TOP $10 \mathrm{~F}$. The results showed that the recombinant of the $p c b C$ gene fragment from $P$. chrysogenum has been obtained. Analysis of DNA sequences using the BLAST program showed that the $p c b C$ gene fragment has high homology (99\%) with the pcbC gene from P. chrysogenum Wisconsin 54-1255 and P. chrysogenum AS-P-78 which encodes IPNS
\end{abstract}

Keywords: pcbC Gene, Penicillium chrysogenum, cloning, penicillin G

\begin{abstract}
Abstrak
Ketersediaan obat di Indonesia masih sangat terkendala dengan mahalnya harga obat akibat ketergantungan impor bahan baku obat yang mencapai 95\%. Upaya mencapai kemandirian bahan baku antibiotik dapat dilakukan dengan pengembangan produksi penisilin G. Antibiotik tersebut merupakan bahan baku bagi pembentukan turunan penisilin semisintetik melalui produksi asam 6-aminopenisilanat (6-APA). Salah satu enzim penentu dalam biosintesis penisilin G adalah Isopenisilin N Sintase (IPNS) yang dikode oleh gen pcbC pada Penicillium chrysogenum. Penelitian ini bertujuan untuk memperoleh rekombinan berupa fragmen gen $p c b C$ yang disisipkan ke dalam plasmid pPICZA. Amplifikasi gen $p c b C$ dilakukan dengan metode Polymerase Chain Reaction (PCR) menggunakan primer pcbC-F dan pcbC-R yang selanjutnya disisipkan ke dalam vektor ekspresi pPICZA dan ditransformasikan ke dalam bakteri kompeten E. coli TOP 10 F'. Hasil penelitian menunjukkan bahwa rekombinan berupa fragmen gen $p c b C$ dari $P$. chrysogenum yang disisipkan ke dalam plasmid pPICZA telah diperoleh. Analisis sekuen DNA menggunakan program BLAST menunjukkan bahwa fragmen gen $p c b C$ tersebut memiliki tingkat homologi yang tinggi (99\%) dengan gen pcbC P. chrysogenum Wisconsin 54-1255 dan P. chrysogenum AS-P-78 yang merupakan pengkode IPNS.
\end{abstract}

Kata Kunci : Gen pcbC, Penicillium chrysogenum, kloning, penisilin G 


\section{PENDAHULUAN}

Kesehatan merupakan faktor fundamental dari suatu negara yang didukung oleh beberapa faktor, diantaranya obat dan ketersediannya di masyarakat. Jenis obat yang dibutuhkan bagi masyarakat Indonesia untuk dikembangkan saat ini adalah dari golongan antibiotik. Data Kementrian Kesehatan RI (2012) menyebutkan hingga tahun 2011 jenis penyakit infeksi masih mendominasi urutan teratas, namun ketersediaan obat di Indonesia masih terkendala dengan mahalnya harga obat akibat ketergantungan impor bahan baku obat yang mencapai 95\%. Hal tersebut menjadikan Indonesia belum dapat dikatakan mandiri dalam sektor bahan baku obat.

Upaya mencapai kemandirian bahan baku obat khususnya antibiotik, dapat dilakukan dengan produksi penisilin $\mathrm{G}$ yang merupakan substrat bagi turunan penisilin semisintetik melalui produksi asam 6-aminopenisilanat (6-APA). Hingga saat ini, 6-APA merupakan bahan baku utama untuk pembuatan penisilin semisintetik yang dapat membuka peluang untuk pengembangan jenis antibiotik lainnya (Sukandar, 2010).

Pengembangan produksi penisilin $\mathrm{G}$ dapat dilakukan melalui pendekatan genetik, yaitu dengan penerapan teknologi kloning gen. Penggunaan teknik kloning gen ditempuh dengan meningkatkan ekspresi gen penyandi enzim kunci biosintesis penisilin G, yaitu dengan cara memindahkan gen tersebut ke dalam suatu sel inang yang dapat mengekspresikan gen dengan aktivitas tinggi.

Kapang yang dapat menghasilkan penisilin untuk skala industri diantaranya adalah Penicillium chrysogenum, sehingga perekayasaan mikroba tersebut hingga saat ini masih terus dilakukan. Gen $p c b C$ pada $P$. chrysogenum berperan dalam mengkode Isopenisilin N Sintase (IPNS) yang merupakan salah satu enzim kunci pada produksi penisilin G. Penggunaan plasmid pPICZA dan Escherichia coli TOP $10 \mathrm{~F}^{\prime}$ yang dirancang untuk memaksimalkan ekspresi protein asing diharapkan dapat mengoptimalkan ekspresi gen $p c b C$ pada perkembangan penelitian selanjutnya.

\section{BAHAN DAN METODE}

Sumber gen menggunakan Penicillium chrysogenum koleksi Balai Pengkajian Bioteknologi, Badan Pengkajian dan Penerapan Teknologi (BPPT). Sel inang (host) dan vektor dalam kloning menggunakan Escherichia coli galur TOP $10 \mathrm{~F}^{\prime}$ dan plasmid pPICZA. Enzim restriksi menggunakan $\mathrm{pml} \mathrm{I}$.

\section{Amplifikasi Fragmen Gen pcbC Menggunakan Polymerase Chain Reaction (PCR)}

Amplifikasi gen $p c b C$ dari $P$. chrysogenum menggunakan LA Taq DNA Polymerase (Takara) dengan pasangan primer pcbC-F dan pcbC-R. Susunan basa nukleotida untuk primer forward (pcbC-F) adalah 5'ATGGCTTCCACCCCCAAGGC'-3, sedangkan susunan nukleotida primer reverse (pcbC-R) yaitu 5'-TCATGTCTGGCCGTTCTTGTTG-'3.

Program PCR terdiri dari denaturasi awal pada suhu $98^{\circ} \mathrm{C}$ selama 1 menit dan 30 siklus reaksi yang terdiri dari denaturasi pada suhu $98{ }^{\circ} \mathrm{C}$ selama 10 detik, penempelan primer pada suhu 58 ${ }^{\circ} \mathrm{C}$ selama 20 detik dan pemanjangan suhu $72{ }^{\circ} \mathrm{C}$ selama 90 detik. Pada tahap akhir proses PCR dilakukan akhir pemanjangan pada suhu $72{ }^{\circ} \mathrm{C}$ selama 5 menit. Gradien pada suhu annealing dilakukan menggunakan PrimeSTAR HS DNA Polymerase dengan suhu yang dioptimasi pada kisaran $50^{\circ} \mathrm{C}-60^{\circ} \mathrm{C}$. Karakterisasi DNA dilakukan menggunakan elektroforesis gel agarosa dengan konsentrasi gel $1 \%$. Molekul DNA dipurifikasi menggunakan Gel/ PCR DNA Fragments Extraction (Geneaid) untuk kloning dan sekuensing.

\section{Isolasi dan Digesti DNA plasmid pPICZA dari E. coli.}

Isolasi dilakukan menggunakan GeneJET Plasmid Miniprep Kit (Fermentas). Karakterisasi DNA plasmid dilakukan dengan elektroforesis gel agarosa pada konsentrasi gel $1 \%$. Konsentrasi diukur menggunakan nanodrop spektrofotometer pada panjang gelombang $260 \mathrm{~nm}$. Tingkat kemurnian didapatkan melalui perbandingan absorbansi pada panjang gelombang $260 \mathrm{~nm}$ dan $280 \mathrm{~nm}$. Digesti plasmid dilakukan menggunakan enzim restriksi Pml I dan penambahan buffer restriksi dengan inkubasi selama 4 jam pada suhu 
$37^{\circ} \mathrm{C}$. Hasil pemotongan DNA dengan enzim restriksi diamati dengan elektroforesis gel agarosa.

\section{Kloning Gen pcbC}

Kloning gen $p c b C$ dari $P$. chrysogenum dilakukan secara bertahap yaitu ligasi pada plasmid vektor, transformasi pada E. coli dan seleksi rekombinan yang membawa plasmid dengan sisipan (insert). Ligasi fragmen gen $p c b C$ ke dalam vektor plasmid pPICZA dilakukan menggunakan enzim T4 DNA ligase dengan rasio molar 3:1. Inkubasi dilakukan pada suhu $4^{\circ} \mathrm{C}$ selama semalam. Hasil ligasi ditransformasi pada bakteri $E$. coli TOP 10 F' kompeten. Transformasi menggunakan teknik kejut panas (heat shock), yaitu dengan perubahan suhu secara mendadak dari inkubasi ice bath ke waterbath $\left(37^{\circ} \mathrm{C}\right)$ selama 2 menit. Bakteri E. coli TOP $10 \mathrm{~F}^{\prime}$ yang telah ditransformasi dikultur dalam LB (Luria Bertani medium) dan diinkubasi selama 30 menit pada $37^{\circ} \mathrm{C}$ dengan kecepatan $150 \mathrm{rpm}$. Seleksi koloni dilakukan dengan menumbuhkan bakteri transforman pada media yang mengandung zeocin. Koloni yang tumbuh merupakan koloni yang diduga mengandung plasmid rekombinan.

\section{Verifikasi hasil kloning}

Verifikasi digesti tunggal menggunakan enzim restriksi Kpn I dilakukan pada transforman kandidat plasmid rekombinan hasil kloning yang telah diisolasi dengan GeneJET Plasmid Miniprep Kit (Fermentas). Inkubasi dilakukan pada suhu $37^{\circ} \mathrm{C}$ selama 4 jam. Hasil digesti dianalisis dengan elektroforesis gel pada $1 \%$ agarosa. Plasmid rekombinan yang telah memberikan hasil positif pada tahap verifikasi digesti, selanjutnya diverifikasi dengan PCR menggunakan pasangan primer pcbC-F dan pcbC-R. Produk PCR yang diperoleh dianalisis dengan elektroforesis gel agarosa $1 \%$.

\section{Sekuensing dan Analisis Sekuen}

Fragmen DNA hasil PCR yang telah diekstraksi dikonfirmasi melalui sekuensing menggunakan primer pcbC-F dan pcbC-R. Proses sekuensing mencakup beberapa tahapan, yaitu PCR cycle sequencing, purifikasi produk cycle sequencing dan pembacaan sekuen melalui elektroforesis kapiler menggunakan alat sequencer ABI PRISM 3130 Genetic Analyzer (Applied Biosystem). Hasil sekuensing diedit dengan perangkat lunak geneious dan BioEdit, kemudian dianalisis homologinya dengan gen yang sama di dalam pusat data Genbank menggunakan pendekatan teknik bioinformatika melalui program BLASTn.

\section{HASIL DAN PEMBAHASAN \\ Amplifikasi Gen pcbC}

Optimasi pada suhu penempelan primer terhadap gen target (annealing) menghasilkan pita pada suhu $58^{\circ} \mathrm{C}$ dengan intensitas yang lebih tebal dibandingkan pita lainnya (Gambar 1). Henegariu et al., (1997) menyatakan tebalnya pita DNA disebabkan pasangan primer berhasil menempel dengan spesifik pada DNA cetakan, yang dipengaruhi oleh ketepatan penggunaan suhu annealing. Suhu yang terlalu tinggi mengakibatkan kualitas penempelan primer pada DNA target menjadi lemah, karena banyaknya ikatan hidrogen yang terlepas, sedangkan suhu yang terlalu rendah mengakibatkan semakin besar peluang terjadinya penempelan primer pada lokasi non spesifik, sehingga terjadi kesalahan pada produk yang dihasilkan bahkan hingga tidak dihasilkan produk sama sekali (Sambrook \& Russell, 2001; Dale \& Schantz, 2002). 


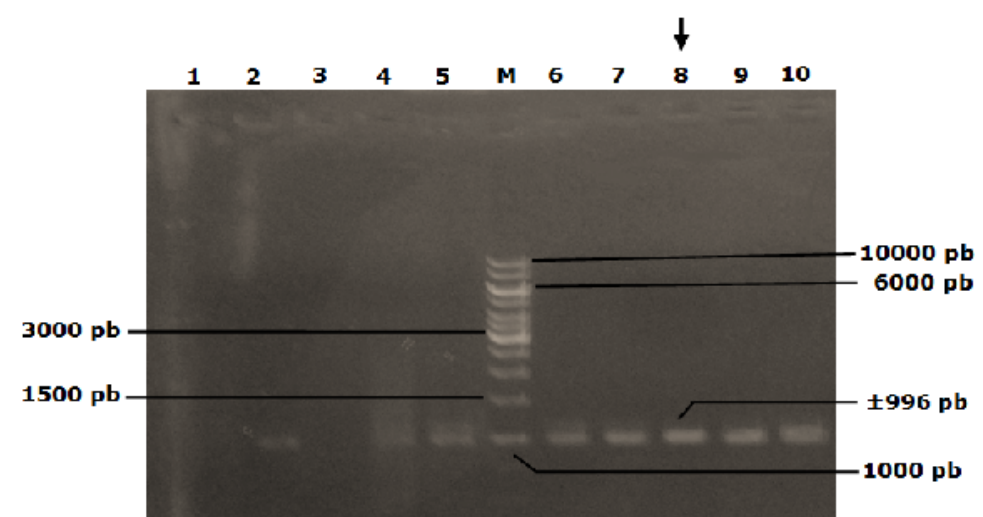

Gambar 1. Profil hasil amplifikasi gen $p c b C$ pada berbagai suhu penempelan primer (lajur 1-5)=hasil amplifikasi berturutturut pada suhu $50^{\circ} \mathrm{C}, 51^{\circ} \mathrm{C}, 52^{\circ} \mathrm{C}$, $53^{\circ} \mathrm{C} \quad \& \quad 54^{\circ} \mathrm{C}$. (lajur 6-10)=hasil amplifikasi berturut-turut pada suhu $55^{\circ} \mathrm{C}, 57^{\circ} \mathrm{C}, 58^{\circ} \mathrm{C}, 59^{\circ} \mathrm{C} \& 60^{\circ} \mathrm{C} . \mathrm{M}=1$ kb DNA LadderI. Panah menunjukkan suhu yang digunakan pada analisis selanjutnya.

Produk PCR pada suhu $58^{\circ} \mathrm{C}$ (Gambar 2) menunjukkan fragmen gen $p c b C$ dari $P$. chrysogenum berukuran $\pm 996 \mathrm{pb}$ yang berhasil diamplifikasi secara spesifik dan tanpa kontaminasi fragmen gen lain, tampak hanya satu pita DNA yang terbentuk dari hasil amplifikasi. Sampel DNA dikatakan spesifik dan berhasil diamplifikasi apabila hasil analisis elektroforesis menunjukkan terdapatnya pita tunggal DNA dengan ukuran sesuai berdasarkan penanda yang telah diketahui sebelumnya (Settanni et al., 2006).

\section{Transformasi}

Keberhasilan transformasi ditandai dengan adanya ekspresi gen resistensi antibiotik yang dibawa plasmid pPICZA sehingga transforman
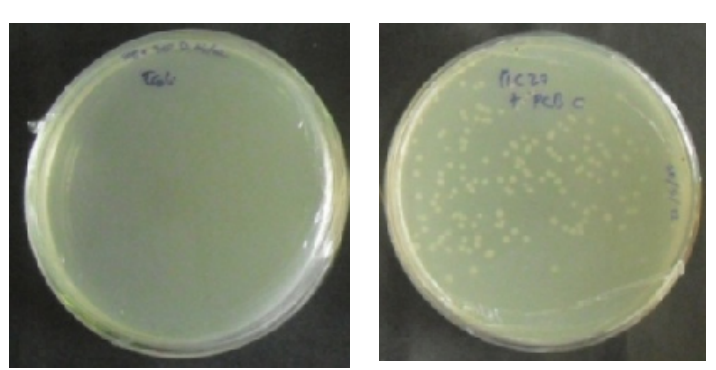

Gambar 3. (a) E. coli TOP 10 F' tanpa plasmid pada medium SOB+zeocin,

(b) hasil transformasi plasmid rekombinan ke dalam E. coli TOP 10 F'
Gambar 2. Amplifikasi gen $p c b C$. Lajur 1=hasil amplifikasi gen $p c b C$ pada suhu annealing $58^{\circ} \mathrm{C} . \quad \mathrm{M}=1 \quad \mathrm{~kb} \quad$ DNA Ladder dapat hidup pada medium yang mengandung antibiotik (medium seleksi) berupa zeocin. Bakteri E. coli TOP 10 F' tanpa plasmid terbukti tidak tumbuh pada medium seleksi (Gambar 3.a), hal tersebut membuktikan bahwa $E$. coli TOP 10 F' bersifat sensitif terhadap zeocin dan tidak terjadi kontaminasi pada tahap pembuatan sel kompeten. Gambar 3.b memperlihatkan adanya koloni tumbuh yang diduga merupakan koloni rekombinan. Masuk dan stabilnya plasmid dalam sel inang mengubah sifat dasar E. coli TOP 10 F' yang semula sensitif terhadap antibiotik zeocin $\left(\mathrm{Zeo}{ }^{\mathrm{S}}\right)$ menjadi resisten terhadap zeocin $\left(\mathrm{Zeo}^{\mathrm{R}}\right)$. 


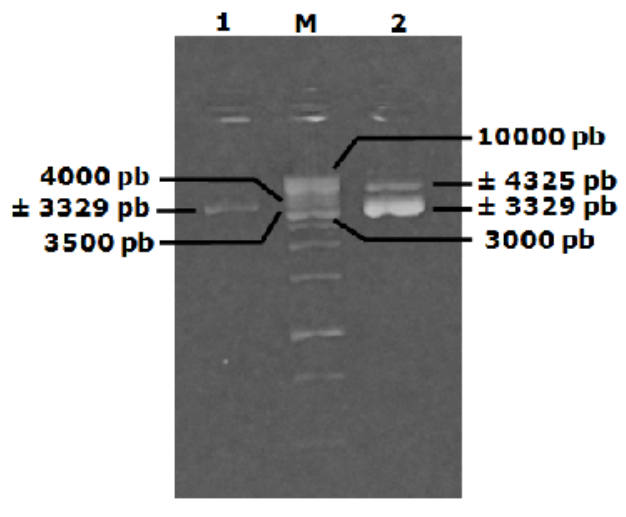

Gambar 3. Digesti Plasmid pPICZA oleh Kpn I. Lajur 1=hasil digesti pPICZA oleh Kpn I. Lajur 2=hasil digesti rekombinan pPICZA- $p c b C$ oleh $K p n$ I. $\mathrm{M}=1 \mathrm{~kb}$ DNA Ladder

\section{Verifikasi Hasil Kloning}

Hasil digesti plasmid rekombinan oleh enzim Kpn I menunjukkan posisi pita yang lebih atas dibanding kontrol berupa digesti plasmid tanpa sisipan, dengan ukuran $\pm 4325 \mathrm{pb}$. Perbedaan pola migrasi DNA antara hasil digesti plasmid rekombinan dan plasmid kontrol yang cukup signifikan mengindikasikan gen $p c b C$ berhasil tersisip pada plasmid pPICZA. Topcu (2000) menyatakan bahwa hasil visualisasi positif terhadap plasmid rekombinan adalah terdapatnya pita-pita DNA yang berada lebih tinggi dari plasmid tanpa DNA sisipan, hal tersebut disebabkan oleh panjang basa plasmid rekombinan yang lebih besar daripada plasmid tanpa DNA sisipan, sehingga pergerakannya di dalam gel agarosa menjadi lebih lambat. Terbentuknya dua pita pada lajur 3 disebabkan terdapatnya plasmid yang mengalami religasi, tampak dari ukuran plasmid yang sama dengan ukuran plasmid pada lajur 1 (Gambar 3) yang merupakan hasil digesti plasmid tanpa sisipan oleh enzim Kpn I.

Verifikasi lebih lanjut menggunakan PCR dilakukan untuk memastikan adanya sisipan gen $p c b C$ pada plasmid rekombinan dan memperkuat hasil verifikasi digesti. Hasil amplifikasi plasmid rekombinan yang memberikan hasil positif pada tahap verifikasi digesti menunjukkan terbentuknya pita DNA yang spesifik dengan ukuran $\pm 996 \mathrm{pb}$

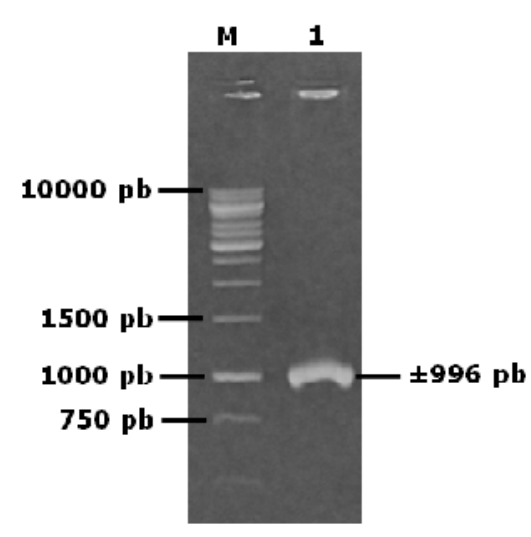

Gambar 4. Verifikasi menggunakan teknik PCR. Lajur 1 \& 2=hasil amplifikasi gen pcbC. $\mathrm{M}=1 \mathrm{~kb}$ DNA Ladder

(Gambar 4). Hasil verifikasi kandidat rekombinan melalui digesti tunggal dan PCR menunjukkan bahwa gen $p c b C$ tersisip dalam plasmid pPICZA.

\section{Analisis Hasil Sekuensing}

Konfirmasi identitas sekuen DNA dilakukan melalui sekuensing fragmen gen $p c b C$ dan penjajarannya dengan sekuen gen yang terdapat pada GenBank. Hal tersebut bertujuan untuk memastikan bahwa gen yang teramplifikasi merupakan fragmen gen target sesuai yang diharapkan. Sekuensing yang dilakukan dua arah menghasilkan sekuen DNA yang berukuran 917 pb. Analisis melalui BLASTn menunjukkan bahwa gen yang tersisip dalam plasmid pPICZA merupakan fragmen gen $p c b C$ yang merupakan pengkode IPNS. Persentase tingkat homologi sekuen nukleotida ditunjukkaan dengan keserupaan hasil penjajaran sekuen yang terlihat dari nilai identitas. Fragmen gen $p c b C$ dalam penelitian memiliki nilai identitas yang mencapai 99\% dengan sekuen gen $p c b C$ dalam spesies yang sama pada strain yang berbeda, yaitu $P$. chrysogenum Wisconsin 54-1255 dan $P$. chrysogenum AS-P-78. Nilai identitas hanya mencapai $85 \%$ pada spesies dalam famili yang sama seperti Aspergillus flavus dan A. oryzae. 
Tabel 1. Hasil BLASTn Fragmen Gen $p c b C$

\begin{tabular}{llll}
\hline No. Aksesi & Deskripsi & Nilai Identitas & E-value \\
\hline XM_002569067.1 & Penicillium chrysogenum 54-1255 & $99 \%$ & 0.0 \\
DQ192518.1 & P. chrysogenum AS-P-78 & $99 \%$ & 0.0 \\
XM_002380605.1 & Aspergillus flavus NRRL3357 & $85 \%$ & 0.0 \\
XM_001825396.1 & A. oryzae RIB40 & $85 \%$ & 0.0 \\
\hline
\end{tabular}

Tingkat homologi juga dapat diketahui dari nilai Expect value (E-value) yang terdapat pada hit list BLASTn. Nilai E-value 0 (nol) pada hasil analisis menunjukkan bahwa kedua sekuen tersebut memiliki homologi yang tinggi. Menurut Claverie \& Notredame (2007), E-value merupakan nilai dugaan yang memberikan ukuran statistik yang signifikan terhadap kedua sekuen. Semakin tinggi nilai E-value maka semakin rendah homologi antara kedua sekuen, sebaliknya semakin rendah nilai $E$-value maka semakin tinggi homologi antara kedua sekuen. Secara teoritis kisaran skor E-value > e-04 pada analisis BLAST menunjukkan tingkat homologi yang tinggi.

\section{KESIMPULAN}

Rekombinan fragmen gen $p c b C$ yang disisipkan ke dalam plasmid pPICZA telah diperoleh dan ditransformasikan dalam sel E.coli TOP 10 F'. Hasil sekuen dan analisis BLASTn menunjukkan bahwa fragmen gen $p c b C$ tersebut memiliki tingkat homologi yang tinggi (99\%) dengan gen $p c b C$ P. chrysogenum Wisconsin 54-1255 dan sP. chrysogenum ASP-78 yang merupakan pengkode Isopenisilin $\mathrm{N}$ Sintase (IPNS).

\section{UCAPAN TERIMAKASIH}

Penelitian dilakukan dengan fasilitas bahan kimia, primer dan alat penunjang di Laboratorium Teknologi Gen, Balai Pengkajian Bioteknologi Badan Pengkajian dan Penerapan Teknologi, Serpong. Ucapan terimakasih disampaikan pada
Dudi Hardianto, M. Si. Apt atas arahan dan bantuan pembiayaan pelaksanaan penelitian.

\section{DAFTAR PUSTAKA}

Claverie, J. \& C. Notredame. 2007. Bioinformatics for Dummies. 2nd edition. Wiley Publishing, Inc, Indiana.

Dale, J. W. \& M. V. Schantz. 2002. From Genes to Genomes Concepts and Applications of DNA Technology. John Wiley \& Sons Ltd, England.

Henegariu, O., N. A. Heerema, S. R. Dlouhy, G. H. Vance \& P. H. Vogt. 1997. Multiplex PCR: Critical parameters and step-by-step protocol. Bio Techniques 23: 504-511.

Kementrian Kesehatan RI. 2012. Profil Data Kesehatan Indonesia Tahun 2011.

Sambrook, J. \& D. W. Russell. 2001. Molecular Clonning : A Laboratory Manual. 3rd Edition. Cold-Spring Harbor Laboratory Press, New York.

Settanni, L., S. Valmori, D. W. Sinderen, G. Suzzi, A. Paparella \& A. Corsetti. 2006. Combination of Multiplex PCR and PCRdenturing gradient gel electrophoresis for monitoring common sourdough-associated Lactobacillus spesies. Applied and Environmental Microbiology 72(5):37933796.

Topcu, Z. 2000. An optimizd recipe for cloning of the polymerase chain reaction-amplified DNA inserts into plasmid vectors. Acta Biochimica Polonica 47(3): 841-846. 